\title{
Pierre Brunel, Monsieur Victor Hugo
}

\section{Lise Sabourin}

\section{(2) OpenEdition}

\section{Journals}

\section{Édition électronique}

URL : http://journals.openedition.org/studifrancesi/33421

DOI : 10.4000/studifrancesi.33421

ISSN : 2427-5856

\section{Éditeur}

Rosenberg \& Sellier

\section{Édition imprimée}

Date de publication : 1 décembre 2005

Pagination : 662

ISSN : 0039-2944

\section{Référence électronique}

Lise Sabourin, «Pierre Brunel, Monsieur Victor Hugo », Studi Francesi [En ligne], 147 (XLX | III) | 2005, mis en ligne le 30 novembre 2015, consulté le 20 avril 2021. URL : http://journals.openedition.org/ studifrancesi/33421 ; DOI : https://doi.org/10.4000/studifrancesi.33421

\section{Ce document a été généré automatiquement le 20 avril 2021.}

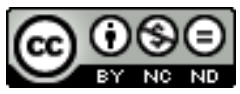

Studi Francesi è distribuita con Licenza Creative Commons Attribuzione - Non commerciale - Non opere derivate 4.0 Internazionale. 


\title{
Pierre Brunel, Monsieur Victor Hugo
}

\author{
Lise Sabourin
}

\section{RÉFÉRENCE}

PIERRE BRUNEL, Monsieur Victor Hugo, Paris, Vuibert, 2002, pp. 192

1 Pour saluer le bicentenaire hugolien à la manière du tableau de Courbet, Bonjour Monsieur Zola!, Pierre Brunel propose, en douze brefs chapitres synthétiques, une biographie qui se révèle aussi scrutation des axes directeurs de la pensée et de l'œuvre entier.

2 Au fil du déroulement chronologique en effet, se lèvent les voiles de la personnalité créatrice. «L'enfant sublime», miraculé d'une naissance fragile, aurore du siècle après une ère crépusculaire, offre la résultante des drames familiaux de la jeunesse: dilemme devant les contradictions politiques des parents, révolte de trois frères amoureux d'une même étoile de gloire et de féminité dont la quête provoque folie et mort. Pour se muer en Olympio, géant cavalier, la bataille d'Hernani doit aussi se livrer contre soi, lion blessé mais pensif, contemplateur de l'être dans son énigmatique destin. Trahison et consolation construisent le passant du siècle, qui est aussi quêteur d'absolu par la mémoire et la douleur. Le silence observé sur les deuils multiples n'évitera la brisure de l'homme que grâce à la mission née de l'histoire. Alors la nécessité de redresser le langage menacé par son dévoiement impérial permet de conjurer l'entropie de la mort: reviviscence du souvenir intime et national, idéalisation et éducation au service de la délivrance populaire, les épopées poétiques et romanesques de l'exil résolvent peu à peu en Hugo ses interrogations métaphysiques de toujours - l'homme est victime de sa pesanteur, des luttes fratricides récurrentes - tandis qu'images et sons jetés à poignées assurent la résurrection d'Orphée, nourri de Renaissance comme d'idylles antiques. Le vieillard héroïsé par Les Misérables, mais vaincu au spectacle de la grâce enfantine, est devenu ce «voyant de l'éternel» (p. 163) que le figement des funérailles nationales n'empêchera pas Mallarmé, Verlaine, Rimbaud, puis Claudel de discerner et continuer. 
3 Mince mais riche, ordonné quoique avec grande liberté, profond sans appesantissement, ce volume comptera désormais parmi les premiers outils hugoliens, en expliquant de surcroît aux néophytes pourquoi l'homme et l'œuvre sont toujours riches d'échos aujourd'hui. 